\title{
An Assessment of Wind Energy Potential as a Power Generation Source in Helwan
}

\author{
Ahmed E. Ghitas, A. Abulwfa, and Yasser A. Abdel-Hadi
}

\begin{abstract}
The wind is an inexhaustible resource that can provide significant quantities of energy to support a country's needs. In this paper, the statistical data of two years wind speed measurements of the Helwan city, Cairo, Egypt are used to find out the wind energy potential. The measurements were carried out by weather station installed above the new building of NRIAG at Helwan (Latitude $=29.5^{\circ} \mathrm{N}$, Longitude $=31.2^{\circ} \mathrm{E}$, Elevation=130 m). Also, other wind characteristics with the help of the meteorological data are assessed to evaluate of which at a height above ground level and in open area. The purpose of this study is to reveal that; the wind potential of this region is suitable for electric wind application in a large-scale or can be adequate for non-grid connected electrical and mechanical applications, such as wind generators for local consumption, battery charging, water pumping, and other utilities.
\end{abstract}

Index Terms-Wind energy potential, wind power density, wind speed, wind turbine, Helwan.

\section{INTRODUCTION}

Among renewable sources of energies, wind energy is an important source of environmental-friendly energy and has become more important in the recent years. This type of energy source is the world's fastest growing energy source that has been in use for centuries in Europe, United States and more recently in Egypt and other nations. Wind turbines, both large and small, produce electricity for utilities and home owners and remote villages. The number of installed wind energy plants is increasing every year and many nations have made plans to make large investments in wind energy in the near future [1].

The wind is an inexhaustible resource that can provide significant quantities of energy to support a country's needs. Since earliest recorded history, man has been harnessing the energy of the wind. There is evidence that wind energy was used to propel boats along the Nile River in Egypt as early as $5000 \mathrm{BC}[2]$.

Egypt occupies a geographical zone between 22 and $32^{\circ} \mathrm{N}$ latitude and 25 and $36^{\circ} \mathrm{E}$ longitude. Although the area of the country is about $998,000 \mathrm{~km}^{2}$, only $3.5 \%$ of it can be said to be permanently settled, while the remainder being desert. The orography of the region has an important role in accelerating and deflecting the wind. Fig. 1 shows the orography of the Egyptian region [3]. Wind energy in Egypt has not been studied thoroughly. Some attempts have been made to analyse the potential in Egypt [3]-[6] and some

Manuscript received May 25, 2015; revised October 12, 2015.

Ahmed E. Ghitas, A. Abulwfa, and Yasser A. Abdel-Hadi are with Department of Solar \& Space Research, National Research Institute of Astronomy and Geophysics NRIAG, Helwan, Cairo, Egypt (e-mail: ahmed_abulwfa@yahoo.com). experimental work [7], [8] has been conducted.

In this paper, an evaluation of wind energy at Helwan desert area in Egypt is done. It is hoped that the data analysis will help to identify good sites for new wind turbine installations. The increase in demand of energy is mainly due to rapid expansion of industrial projects and the economic growth, particularly, in the extreme northwest of Egypt.

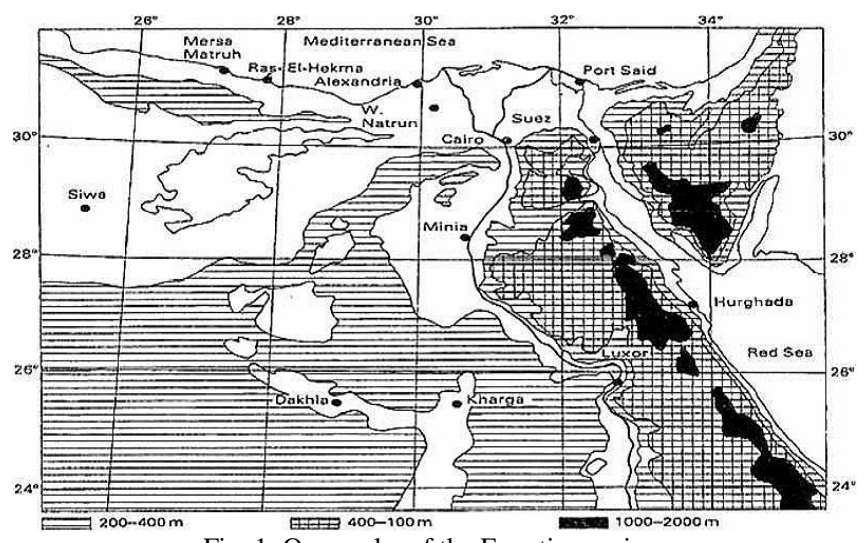

Fig. 1. Orography of the Egyptian region.

The measurements were carried out by weather station installed on the rooftop of the new building of the National Research Institute of Astronomy and Geophysics (NRIAG) at Helwan which has latitude $29.5^{\circ} \mathrm{N}$ and longitude $31.2^{\circ} \mathrm{E}$, the station elevation is $130 \mathrm{~m}$ above sea level. Fig. 2 shows the site under studying on which the station is situated.

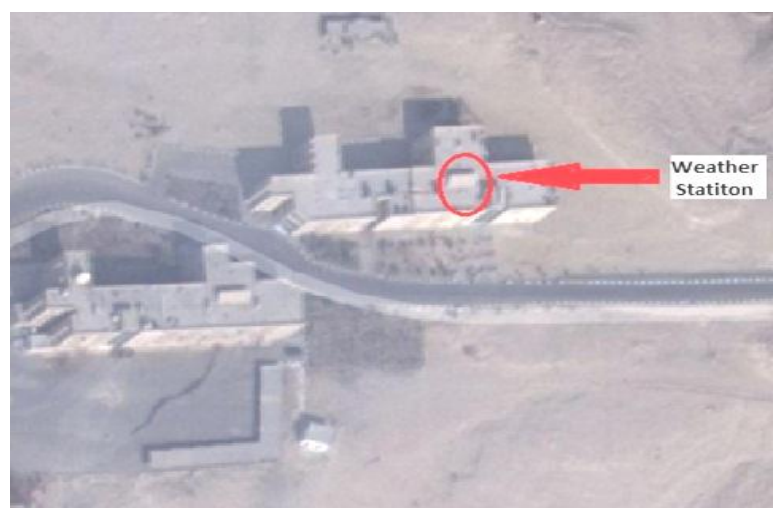

Fig. 2. A view of the studied site where the station is situated on the rooftop of NRIAG building at Helwan.

\section{RESULTS AND DISCUSSION}

In this study, wind speed data for Helwan of two-year period from 2011 to 2012 were analyzed. Based on these data, the mean wind speeds were analyzed. Calculations were then made to obtain the mean wind power. The main results obtained from the present study can be summarized 
as follows.

Having analyzed the 24 months of wind speed data, it can be concluded that the wind speed distribution differs remarkably from one month to the next. The monthly and yearly standard deviation values are mostly between 1.50 and $3.00 \mathrm{~m} / \mathrm{s}$, with only few records less than $1.50 \mathrm{~m} / \mathrm{s}$. The monthly mean wind speeds are illustrated in Fig. 3 and Fig. 4.

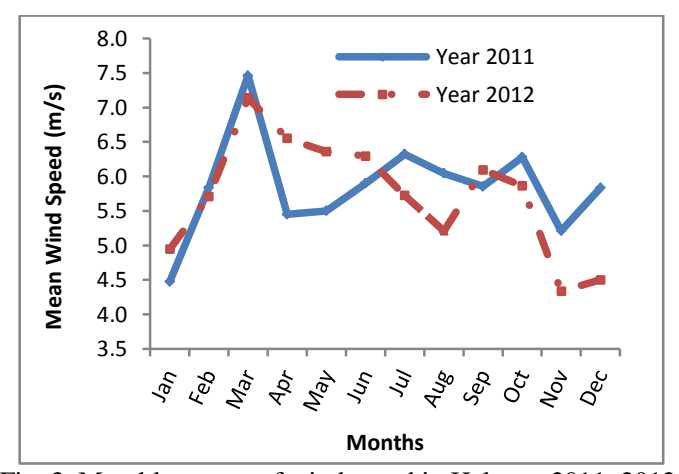

Fig. 3. Monthly means of wind speed in Helwan, 2011-2012.

It is also clear from the latter figures that the whole year wind speed has the lowest values in November, while the highest values in March, ranging from 4.33 to $7.46 \mathrm{~m} / \mathrm{s}$ with an annual average of $5.787 \mathrm{~m} / \mathrm{s}$.

The mean monthly averages of wind speed beside the annual means are listed in Table I. The table indicates that most of months have speed more than $4.4 \mathrm{~m} / \mathrm{s}$ expect November 2012 and the annual mean wind exceed $5.7 \mathrm{~m} / \mathrm{s}$ for the two years. Fig. 4 illustrates the monthly mean of wind speed for all years. It is clear from the figure that the Helwan zone is windy.

TABLE I: Mean Monthly AND ANNuAl Wind SPEed (M/s) At Helwan

\begin{tabular}{|l|l|l|}
\hline Months & $\mathbf{2 0 1 1}$ & $\mathbf{2 0 1 2}$ \\
\hline Jan. & 4.47 & 4.94 \\
\hline Feb. & 5.84 & 5.71 \\
\hline Mar. & 7.46 & 7.14 \\
\hline Apr. & 5.45 & 6.55 \\
\hline May & 5.5 & 6.36 \\
\hline Jun. & 5.9 & 6.3 \\
\hline Jul. & 6.32 & 5.72 \\
\hline Aug. & 6.05 & 5.21 \\
\hline Sep. & 5.85 & 6.1 \\
\hline Oct. & 6.28 & 5.86 \\
\hline Nov. & 5.21 & 4.33 \\
\hline Dec. & 5.83 & 4.5 \\
\hline Annual mean & 5.847 & 5.727 \\
\hline
\end{tabular}

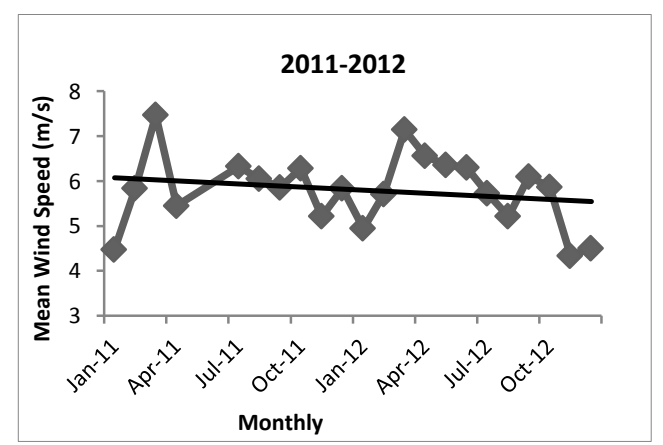

Fig. 4. Monthly variation of wind speed for two years at Helwan station.
In Helwan, the higher heating demand also occurs from November to March, which can be grouped as the cold season. The wind energy may be applied as a supplement to the current gas or electric heating. The time interval from April to October is the warm season in Helwan. For the cold season, the two-year- mean wind speed is $5.544 \mathrm{~m} / \mathrm{s}$, while the warm season means wind speed is $5.961 \mathrm{~m} / \mathrm{s}$. Table II shows that the means of wind speed in the warm season are higher than those in the cold season. It also shows that the higher wind speeds coupled with the warmer dense air combine to deliver a higher energy yield when the power (electricity) demand is higher in these months for air conditioning.

TABLE II: YEARLY MEAN WIND SPEED VARIATION IN (M/S) FOR COLD SEASON (NOVEMBER-MARCH) AND WARM SEASON (APRIL-OCTOBER) BASED ON TWO-YEAR-DATA (2010-2012) IN HELWAN

\begin{tabular}{|l|l|l|}
\hline Year & Cold season & Warm season \\
\hline $\mathbf{2 0 1 1}$ & 5.763 & 5.907 \\
\hline $\mathbf{2 0 1 2}$ & 5.325 & 6.014 \\
\hline Whole year & 5.544 & 5.961 \\
\hline
\end{tabular}

During the winter season, the wind speed level decreases to $5.544 \mathrm{~m} / \mathrm{s}$. This can be interpreted by the decrease of the temperature during winter months.

\section{DIURNAL WIND SPEED VARIATIONS}

The diurnal wind speed variations are illustrated in Fig. 5. The bell shaped trend can be found for the curves. It can be found that the daytime, from 8 a.m. to 8 p.m., is windy for all years, while the night time is relatively calm. The hourly means increase at around $6 \mathrm{a} . \mathrm{m}$. and the peaks are at around 2 p.m. After that, the afternoons are characterized by decreasing wind speeds, which tend to settle to lows after 8 p.m. There is a good coincidence between the energy demands and the characteristics of Helwan wind speed since normally the energy demand is higher in the daytime.

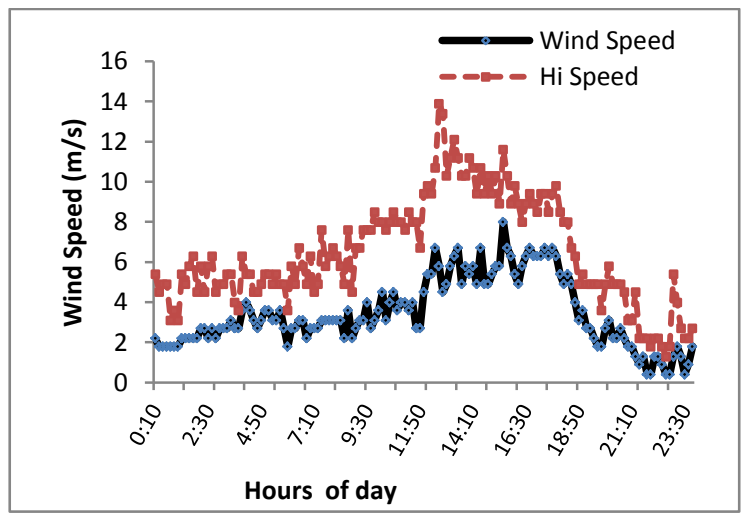

Fig. 5. Diurnal variation of wind speed in Helwan, Egypt, 2012.

\section{WIND POWER ESTIMATION AND ANALYSIS}

The specific power available in a cross-sectional area (A) perpendicular to the wind stream moving at speed $\mathrm{V}(\mathrm{m} / \mathrm{s})$ is calculated and expressed per unit area as follows [9]-[12].

$$
P_{\text {wind }}=\frac{1}{2} \rho \bar{V}^{3}\left(\mathrm{~W} / \mathrm{m}^{2}\right)
$$


where $\rho$ is the standard air density $\left(1.225 \mathrm{~kg} / \mathrm{m}^{3}\right) . \bar{V}^{3}$ is the mean wind speed $(\mathrm{m} / \mathrm{s})$.

Then, the corrected monthly air density $\bar{\rho}_{-}\left(\mathrm{kg} / \mathrm{m}^{3}\right)$ is calculated as follows:

$$
\bar{\rho}=\frac{\bar{\rho}}{R_{d} \bar{T}}
$$

where $\bar{P}$ is the monthly average air pressure $\left(\mathrm{N} / \mathrm{m}^{2}\right), \bar{T}$ is the monthly average air temperature $(\mathrm{K}), R_{d}$ is the gas constant for dry air $\left(R_{d}=287 \mathrm{~J} / \mathrm{kg} . \mathrm{K}\right)$.

The corrected power available in wind at a height of $10 \mathrm{~m}$ can be calculated as follows:

$$
P_{10}=\frac{1}{2} \bar{\rho} \bar{V}^{3}\left(\mathrm{~W} / \mathrm{m}^{2}\right)
$$

The monthly corrected and uncorrected wind power $\left(P_{10}\right.$, $\left.P_{\text {wind }}\right)$ were calculated using (1) and (3) and the results lead to Fig. 6.

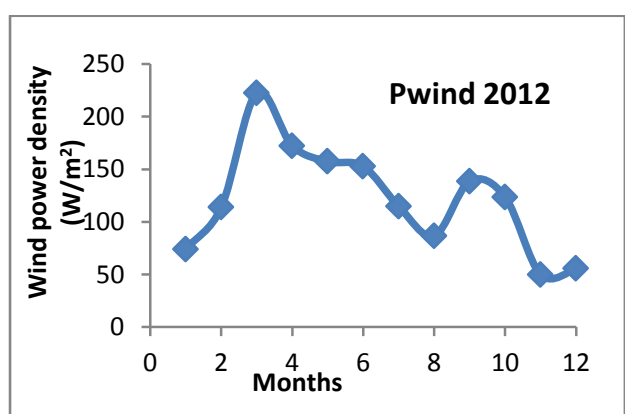

Fig. 6. Monthly variation of the wind power density for year 2012 in Helwan.

Annual values of corrected wind power $P_{10}$ are always smaller than the uncorrected wind power, $P_{\text {wind }}$. This deviation is important because the sizing and the costing of any technical wind system depends mainly on the wind power.

For simplicity, when considering the calculation of monthly corrected wind power, $P_{10}$, from the monthly uncorrected values, $P_{\text {wind }}$, a correlation between $P_{10}$ and $P_{\text {wind }}$ has been investigated and illustrated in Ref. [13]. A strong linear fit has been found between $P_{10}$ and $P_{\text {wind }}$, where we obtain a correlation coefficient of $\mathrm{CC}=0.99$. The recommended correlation equation is:

$$
P_{10}=P_{\text {wind }}-0.5414
$$

Eq. (4) is quite practical can be used to calculate P10, along the Helwan desert area in Egypt.

\section{CAlCulation of Wind Power Density}

The wind power density is evaluated, respectively, by (1) and (3) and shown in Table III. It is clear that the highest value of wind power density was in 2011 and followed by 2012.

As seen in Fig. 6, dramatic monthly changes in the wind power density were found with a maximum value (223
$\mathrm{W} / \mathrm{m}^{2}$ in March) being 4.46 times of the minimum $\left(50 \mathrm{~W} / \mathrm{m}^{2}\right.$ in November). Such considerable difference in the wind power density may be accounted for the fact that the power is proportional to the cube of the wind speed, which is doubled from August to April as showed in Fig. 6. Table III represents the calculated values of the wind power density for the whole months of the two years. The significant monthly change underscores the importance of distinguishing different months of the year when a wind power project is assessed or designed.

TABLE III: MONTHLY WIND POWER DENSITY (W/M²) FOR WHOLE YEARS IN HELWAN

\begin{tabular}{|l|c|c|}
\hline & \multicolumn{2}{|c|}{ Wind power density $\left(\mathbf{W} / \mathbf{m}^{\mathbf{2}}\right)$} \\
\hline Months & $\mathbf{2 0 1 1}$ & $\mathbf{2 0 1 2}$ \\
\hline Jan. & 55 & 74 \\
\hline Feb. & 122 & 114 \\
\hline Mar. & 254 & 223 \\
\hline Apr. & 99 & 172 \\
\hline May & 102 & 157 \\
\hline Jun. & 126 & 153 \\
\hline Jul. & 155 & 115 \\
\hline Aug. & 135 & 87 \\
\hline Sep. & 123 & 139 \\
\hline Oct. & 152 & 123 \\
\hline Nov. & 87 & 50 \\
\hline Dec. & 122 & 56 \\
\hline
\end{tabular}

\section{CONCLUSIONS}

From the statistical data and calculations, we can conclude that:

The wind energy potential along the Helwan desert south Cairo Egypt is quite promising because the chances of having wind speeds less than $4.4 \mathrm{~m} / \mathrm{s}$ are small, see Table I.

Because the wind speed range for electricity generation is (5-6) $\mathrm{m} / \mathrm{s}$ [14], Helwan site is suitable for the electric wind applications.

Investigation of available wind power density at the height of $15 \mathrm{~m}$ indicates that Helwan has high wind power density ranging from $122-254 \mathrm{~W} / \mathrm{m}^{2}$ at this height. So, wind farms can be installed in this region to supply a reasonable amount of energy using a number of wind turbines.

\section{REFERENCES}

[1] S. A. Akdağ and Ö. Güler, "Evaluation of wind energy investment interest and electricity generation cost analysis for Turkey," Applied Energy, vol. 87, pp. 2574-2580, 2010.

[2] Wind Energy: Technical Information Guide, Solar Energy Research Institute, US Department of Energy, 1989.

[3] M. Rizk, "Wind characteristics and the available wind energy in Egypt," Solar and Wind Technology, vol. 4, no. 4, pp. 491-499, 1987.

[4] D. S. Renne, D. L. Elliott, B. D. Holst, and K. El-Bassyouni, "Wind energy resource assessment activities in Egypt," in Proc. European Wind Energy Association Conference and Exhibition, 1986, pp. 299304.

[5] H. M. Abu El-Eizz, M. K. Al-Motawakel, and Z. A. A. El-Eizz, "Wind characteristic and energy potentialities of some selected sites in the Yemen Arab Republic and the Republic of Egypt," Renewable Energy, vol. 1, no. 5, pp. 675-81, 1991.

[6] D. L. Elliott, D. S. Renne, and K. Bassyouni, "Wind energy resource assessment of Egypt," in Proc. the Sixth ASME Wind Energy Symposium, 1987, vol. 3, pp. 215-216.

[7] N. G. Mortensen and U. Said, "Wind atlas for the gulf of Suez, Arab Republic of Egypt," in Proc. European Wind Energy Conference, Measurements and Modeling, 1996, pp. 623-626. 
[8] K. Fouad, "A small locally produced windmill for electric power generation as a model for small industry," Renewable Energy, vol. 6, no. 5, pp. 629-32, 1995.

[9] A. S. Ahmed, "Site potential of Egypt for wind energy applications," MSc thesis, Faculty of Science, Zagazig University, Egypt, 2000.

[10] A. S. Ahmed, "Investigation of wind characteristics and wind energy potential at Ras Ghareb, Egypt," Renewable and Sustainable Energy Reviews, vol. 15, pp. 2750- 2755, 2011.

[11] A. Keyhani, M. Ghasemi-Varnamkhasti, M. Khanali, and R. Abbaszadeh, "An assessment of wind energy potential as a power generation source in the capital of Iran, Tehran," Energy, vol. 35, pp. 188-201, 2010.

[12] W. Wolde-Ghiorgis, "Wind energy survey in Ethiopia," Solar and Wind Technology, vol. 5, no. 4, pp. 341-51, 1988.

[13] A. S. A. Shata and R. Hanitsch, "Evaluation of wind energy potential and electricity generation on the coast of Mediterranean Sea in Egypt," Renewable Energy, vol. 31, pp. 1183-1202, 2006.

[14] L. O. Adekoya and A. A. Adewale, "Wind energy potential of Nigeria," Renewable Energy, vol. 2, no. 1, pp. 35-39, 1992.

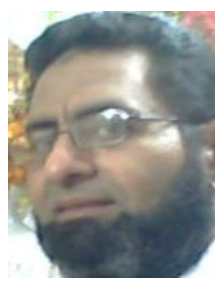

Ahmed E. Ghitas was born in Kalubia, Egypt, on October 31,1965 . He is a professor of solar energy, at the Department of Solar \& Space Research, National Research Institute of Astronomy and Geophysics (NRIAG), Helwan, Cairo, Egypt.

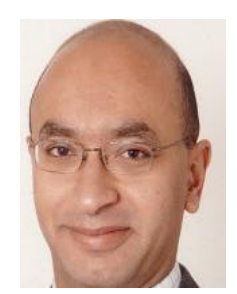

Yasser A. Abdel-Hadi was born in Cairo, Egypt, on June 7, 1969. He is an associate professor of solar energy, at the Department of Solar \& Space Research, National Research Institute of Astronomy and Geophysics (NRIAG), Helwan, Cairo, Egypt.

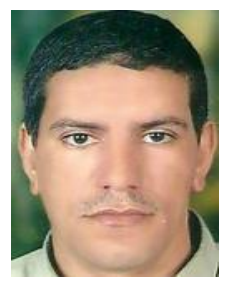

Ahmed Abulwfa was born in Qena, Egypt, on September 13, 1979. He received the master degree in 2013. Currently, he is a Ph.D. student of solar energy at the Department of Solar \& Space Research, National Research Institute of Astronomy and Geophysics (NRIAG), Helwan, Cairo, Egypt. 


\section{Energy-Saving Technology}


